\title{
SKEPPING, GELOOF EN EVOLUSIONISME
}

\author{
Prof. dr. L. B. C. Jansen. Dept. Veeartsenykunde, U.P.
}

Ten einde die begrippe skepping, geloof en evolusionisme in die regte perspektief te sien, is dit nodig om die benadering en denkwyse van die mense wat hulle met die onderskeie begrippe besig hou, te ontleed.

\section{DIE STANDPUNT VAN DIE EVOLUSIONIS}

Evolusionisme is gebaseer op die konsepte van spontane generasie en natuurlike seleksie. Sonder spontane generasie en veral natuurlike seleksie is evolusionisme geheel-en-al dood. Alhoewel dit in verskeie werke van vooraanstaande evolusioniste gedokumenteer staan dat hulle hele wetenskapsbeskouing op hierdie twee steunpilare rus, pas baie van hulle nie die konsekwensies hiervan in hulle redenasies toe nie.

Met spontane generasie word bedoel dat alle lewende wesens, organismes en plante spontaan ontstaan het uit 'n lewelose oermassa deur die lukraak bymekaarvoeging van atome as 'n gevolg van die vrystelling van ' $n$ onbekende bron van energie. Daar is geen sprake van 'n rigtinggewende $\mathrm{krag}$ agter hierdie proses nie. Die oorsprong van die oermassa en die oorgang van lewelose materie na die lewende wese word nie verklaar nie, terwyl dit tog kardinale punte is.

Volgens die konsep van natuurlike seleksie het alles wat lewe ontstaan vanuit een oer-organisme oor 'n tydperk van $3 \frac{1}{2}$ biljoen jare. Basies beteken natuurlike seleksie dat gesonde en lewenskragtige organismes of wesens ' $n$ beter kans het op oorlewing en vermenigvuldiging as siekeriges of tingeriges in dieselfde gemeenskap. Op so 'n manier word swak eienskappe in 'n bevolking van organismes onderdruk en uitgeskakel en goeies bewaar met die gevolg dat daar 'n voortdurende neiging bestaan om 'n verbetering van die organismes in die bevolking teweeg te bring. Natuurlike seleksie gebeur nie doelgerig nie, dit is die selfgenerende resultaat van die interaksie tussen die organismes en hulle omgewing.

Die evolusioniste beweer dat daar geen evolusionére vordering deur natuurlike seleksie kan teweeggebring word nie as daar nie 'n bron van genetiese veranderlikheid in die samestelling van die organismes is nie, d.w.s. sonder die voorkoms van oorerflike veranderinge kan die lewende dinge nie ontwikkel of verskeidenheid bewerkstellig nie. Sonder genetiese veranderinge sou net dieselfde soort organismes wat $3 \frac{1}{2}$ biljoen jare gelede bestaan het, vandag nog gelewe het, en geen ander ander nie omdat daar dan nie beter individue sou kon ontstaan om die swakkeres uit te druk nie.

Die evolusioniste beweer dat die bron van genetiese verskeidenheid die proses van mutasie is. Normalerwys word die genetiese materiaal van 'n organisme gedurende reproduksie presies getrou voortgeplant in sy afstammelinge. Soms egter onstaan daar in die proses van vermenigvuldiging op 'n lukraak manier foute in die genetiese samestelling van die afstammelinge. Hierdie foute heet mutasies en die veranderde afstammeling heet 'n mutant. Mutasie is in werklikheid ' $n$ totaal ongerigte, doellose proses wat as niks 
anders as 'n fout in die genetiese samestelling van 'n organisme kan beskryf word nie. Meestal lei dit tot die dood van die sel waarin dit plaasvind. As die mutant volgens die evolusieteorie per toeval beter aangepas is aan sy omgewing as sy ouer van oorsprong sal hy deur natuurlike seleksie bevoordeel word tot so 'n mate dat hy tesame met sy afstammelinge die stam waaruit hy ontstaan het sal verplaas. So ontstaan met die jare in die bepaalde omgewing 'n populasie van organismes met die genetiese samestelling van die mutant. Die proses herhaal homself en na herhaalde trappe van verbetering ontstaan hoër diersoorte uit laeres. So, sê die evolusionis, het trapgewys ook die mens ontstaan uit sy voorouer, die aapmens, wat weer op sy beurt uit laere wesens ontstaan het deur natuurlike seleksie.

Die werkswyse van die evolusioniste bestaan daarin dat hulle in die eerste instansie onderwerpe bestudeer wat tot die verlede behoort, bv. 'n stukkie versteende been word uitgegrawe en word daarvan 'n skelet opgebou van 'n veronderstelde wese wat inpas by hulle teoretiese opvattings. Die gevolg is dat alle argeologiese en paleontologiese ontdekkings ingeskakel word in hipoteses wat strook met hulle benadering. Modelle en stambome word ontwikkel wat meer die produk is van fantasie as wetenskaplike redenasie. Die voorwerpe van hulle studie leen hulle nie tot volledige wetenskaplike analise nie omdat hulle geen verband het met enigiets wat huidig nog bestaan nie. Dit lei tot hoogs teoretiese aannames en lewer meestal wetenskaplik onverantwoordbare konklusies wat dikwels deur hulle self moet gewysig word. As voorbeeld hiervan dien die hipotese dat 'n perd, wat een toon aan elke voet het, afstam van 'n dier wat drie tone aan elke voet het. In Oregon, V.S.A., is daar egter fossiele van perde gevind in dieselfde rotsformasie as fossiele van die drietonige dier maar dit skyn asof hierdie feit verswyg word. Vanuit hierdie twyfelagtige teorieë word verklarings gebied vir die waarnemings van wetenskaplikes op huidig bestaande natuurverskynsels, d.w.s. van die onbekende en meestal onpeilbare na 'n poging tot 'n verklaring van wat tans waargeneem word - beslis 'n onlogiese benadering.

Hierdie benadering beweeg ' $n$ evolusionis daartoe om te beweer dat al die hemelliggame spontaan ontstaan het uit 'n enkele massa deur 'n ontploffing. Die brokke wat daaruit ontstaan het, het dle hemelliggame gevorm en hulle is nog besig om uitmekaar te beweeg. Hierdie siening hou nie rekening met die ondeurgrondelike onmeetbaarheid van die hemelruim en dat elke liggaam in die kosmos sy bepaalde plek en wentelbaan het, ook nie met die feit dat daar 'n geordende verhouding tussen hulle bestaan, bv. die aarde en die son.

\section{DIE STANDPUNT VAN DIE GELOWIGE}

Die benadering van die gelowige tot die probleme onder bespreking is gebaseer op wat in die Bybel geopenbaar is en op sy bestudering van die Natuur.

Die Bybel is die Boek van die religie, van die openbaring en die kennis van God. Volgens die Nederlandse Geloofsbelydenis bevat die Bybel "soveel naamlik as wat ons nodig het in hierdie lewe, tot Sy eer en die saligheid van wie aan Hom behoort". Die Bybel is dus 
nie 'n wetenskaplike handboek nie en werp lig op sake wat die wetenskap nooit kan ontdek nie. Watter wetenskaplike weet, byvoorbeeld, wat die toedrag van sake was voordat die skepping in aansyn geroep is?

Enige saak wat in die Bybel genoem word wat vir wetenskaplike interpretasie vatbaar is, word nie vermeld omrede van sy wetenskaplike betekenis nie, maar wel omrede van sy religieuse betekenis. As daar in 1 Sam. 2:8 vermeld word ,want aan die Here behoort die pilare van die aarde, en $\mathrm{Hy}$ het die wêreld daarop gevestig" beteken dit nie dat, in terme van moderne wetenskaplike opvattings, die Bybel verkeerd is nie. Die bedoeling van 1 Sam. $2: 8$ is om die grootheid en almag van God te besing en nie om 'n eksakte les in Aardrykskunde te wees nie.

Watter wetenskaplike was teenwoordig by die Skepping sodat hy 'n korrekte weergawe in moderne idioom kon gee van die gebeure? Dit is dus verkeerd om die eerste hoofstukke van Genesis vanuit 'n wetenskaplike oogpunt te ontleed, want dit gaan bloot om 'n magtige proklamasie van God dat Hy die Oorsprong van alles is. Dit gaan om die religieuse waarde van die eerste hoofstukke van Genesis en nie om die wetenskaplike korrektheid daarvan nie.

Die Bybel en evolusionisme beweeg op totaal verskillende gebiede. Hoe kan dit dan reg wees om die Bybel se korrektheid te toets aan die evolusiehipotese wat in die begin van die $19 \mathrm{e}$ eeu ontstaan het en in sovele opsigte al verkeerd bewys is? Omgekeerd is dit wel nodig om die God-loosheid van die evolusionisme te verwerp op grond van die Bybelse leer. Dit is egter nie nodig om op grond van die Bybel die onwetenskaplikheid van die evolusionisme te bestry nie, want die moderne wetenskap verwerp dit effektief genoeg.

Daar bestaan geen moontlikheid van versoening tussen die Bybelse standpunt en evolusionisme nie, en evolusioniste se manier om voortdurend te verwys na die bekrompenheid van diegene wat 'n Bybelse benadering handhaaf is eerder ' $n$ bewys van die swakheid van hulle argumente as dat dit oortuigende waarde besit.

\section{DIE WETENSKAPLIKE BENADERING}

Die doel van die natuurwetenskaplike is om al die eienskappe en verskynsels wat lewende wesens en dooie materie in die natuur toon, te bestudeer in diepte met al die moderne tegnieke tot sy beskikking.

Deur die jare wat talle natuurwetenskaplikes met die nodige objektiwiteit en regte insig hiermee besig was, is daar baie oortuigende inligting versamel wat die basiese uitgangspunte van die evolusioniste geheel-en-al weerspreek en van enige oortuigingskrag beroof. Net enkele aspekte hiervan sal vir die doel van hierdie referaat behandel word.

\section{DIE HIPOTESE VAN SPONTANE GENERASIE}

As spontane generasie 'n werklikheid was, sou mens kon aanvaar dat die kleinste, eenvoudigste lewende organisme eerste moes ontstaan het en dan deur vermenigvuldiging, mutasie en natuurlike seleksie tot 'n groter organisme sou ontwikkel. Maar nou weet ons uit ons moderne studies dat die kleinste organismes, $\mathrm{nl}$. virusse 
of viroïede nie onafhanklik van 'n hoër lewende wese soos 'n mens of dier se weefsels kan bestaan of vermenigvuldig nie. Dus kon die kleinste lewende wese nie op die wyse soos die evolusioniste dit sien die hele proses van evolusie aan die gang gesit het nie. As die evolusioniste met hierdie harde feit gekonfronteer word, beweer hulle dat 'n hoër meer komplekse organisme soos 'n Mikoplasma (wat wel onafhanklik kan bestaan) eerste ontstaan het en dat virusse die produk van degenerasie van die hoër vorm is. Eerstens is dit onlogies selfs teen die agtergrond van evolusionistiese denkwyse dat 'n meer komplekse organisme eerder as 'n eenvoudige organisme spontaan sal ontstaan en tweedens is die toegewing dat 'n komplekse organisme kan degenereer tot 'n eenvoudiger afhanklike vorm 'n erkenning van devolusie liewer as evolusie. Hoe kan 'n eerlike wetenskaplike dan mense wat so redeneer oortuig? Nog 'n argument kan teen spontane generasie ingebring word. Eers moet 'n paar moderne basiese biologiese begrippe omskryf word.

Daar bestaan in elke lewende sel, hetsy van 'n eensellige organisme of van 'n meersellige lewende wese, 'n universele kodepatroon wat bekend staan as die DNS-molekuul. Op hierdie kodepatroon word die proteïene wat die essensiële deel is van elke sel gevorm deur aaneenskakeling van die boustene, aminosure. Geen proteïene kan egter gevorm word sonder die DNS-molekuul nie. Hierdie DNS-molekuul bevat die genetiese inligting wat veroorsaak dat die proteïene wat binne-in die sel van 'n vis, byvoorbeeld, gevorm word, anders is as die proteïene binne-in die sel van 'n skaap.

'n Sel van 'n dier bevat baie DNS-molekule wat, as dit aaneengeskakel word, 'n draad van sowat 2 meter lank kan wees. Die DNSdraad bestaan uit duisende atome van koolstof, waterstof, suurstof, stikstof en fosfor wat in presies die regte volgorde moet aaneengeskakel wees anders kan dit nie funksioneer nie. Verder moet al die duisende atome ook nog in die regte ruimtelike verhouding tot mekaar ingespan wees anders kan die DNS ook nie funksioneer nie.

Die statistiese kans dat so 'n DNS-draad uit 'n dooie oermassa spontaan kan ontstaan deur die toedien van 'n donderslag of ander vorm van energie, is seker net so groot as wat die kans is dat ' $n$ volledige Bybel gevorm word as 'n bom 'n drukkery tref.

Die evolusioniste bly aan die denkende mensdom ook nog 'n verklaring verskuldig van hoe daar lewe ontstaan het in die produk van samesmelting van atome in die dooie sogenaamde oermassa.

Verder het die moderne wetenskap onomwonde bewys dat die DNS binne-in 'n lewende sel nie proteïene kan vorm nie as daar nie reeds volledige proteïene in die vorm van ensieme in die sel teenwoordig is nie. Daar moes dus volledige proteïene geskep gewees het voordat proteïen-sintese d.m.v. DNS aan die gang kon kom. Hoe kan mens hier by die bestaan van 'n transedente Skepper verbykom?

Die werklikheid van die skepping word halsstarrig deur die evolusioniste ontwyk.

\section{DIE HIPOTESE VAN NATUURLIKE SELEKSIE}

Die feit dat natuurlike seleksie soos dit in die begin van hierdie 
referaat omskryf is, wetenskaplik onhoudbaar is, sal aan die hand van net 'n paar van vele voorbeelde bewys word.

Die menslike liggaam ontstaan in sy embrionale stadium uit 'n enkele bevrugte eiersel. Hierdie sel ondergaan dan herhaalde tweedeling totdat op ' $n$ stadium differensiasie in die selle intree. Dit beteken dat sommige van die selle lewerselle word, ander word hartspierselle, ander breinselle. So differensieer die selle wat presies dieselfde genetiese samestelling het om al die verskillende weefstels van die liggaam te vorm. Op die end lyk die selle van die verskillende weefsels heeltemal verskillend met heeltemal verskillende funksies.

Verder het elke orgaan wat deur die verskillende tipes selle gevorm word sy eie vorm en as hy in die embrionale stadium sy tipiese vorm bereik het, hou die selle op met hulle vorige verdelingsproses. Oplaas vorm al die verskillende organe 'n intergrale deel van 'n perfek funksionerende liggaam waarin al die organe se funksies perfek gekoordineer is. Die oog, byvoorbeeld, kan homself aanpas by die intensiteit van die lig en die beeld wat hy sien oordra aan die brein wat op sy beurt 'n boodskap oordra aan die spiere en kliere. Laasgenoemde beïnvloed weer die hartfunksies om in te pas by die reaksie wat in die spiere verwerk word. Die mens se oor ontvang klankgolwe en dra dit oor aan die brein wat dit verwerk tot konsepte wat op hulle beurt weer aanleiding gee tot reaksies, hetsy in die vorm van spraak of optrede. Die mens kan idees skep en gedagtes wissel. Ook besit hy 'n verantwoordelikheidsin, etiese waardes en kan hy rasioneel optree.

Hoe kan hierdie differensiasie, spesialisasie kompleksiteit en perfekte koördinasie deur 'n lang reeks van mutasies of sogenaamde genetiese foute op 'n lukraak manier ontstaan? Die voorbeeld van die menslike liggaam spreek van uiterste gerigtheid en 'n lukraak proses vertoon geen gerigtheid nie.

Die kameelperd (giraffe) kan as tweede voorbeeld dien om te bewys dat natuurlike seleksie nie 'n verklaring bied vir die ontstaan van verskillende diersoorte nie.

Die kameelperd wat 6 meter hoog kan staan, het 'n bloeddruk wat tenminste tweemaal so hoog is as dié van 'n bees om sodoende gedurig voldoende bloed by sy brein te kry. Verder het die kameelperd nie 'n orgaan bekend as die karotus sinus nie. Hierdie orgaan wat by ander diere teenwoordig is, laat die bloeddruk daal as die dier rus. Die kameelperd kan ' $n$ daling in sy bloeddruk nie bekostig nie. Hy het ook nog 'n stel kleppe in die are van sy borskas en bene wat verhoed dat die bloed van sy hart af wegsak in sy bene sodat die hart altyd genoeg bloed het om na die brein te pomp. Ander diere het nie hierdie kleppe nie.

Bykomstig tot die hoë bloeddruk in die are wat na die brein toe lei, word die druk nog aansienlik verhoog as die kameelperd sy kop laat sak om te drink. Maar geen dier se brein kan hierdie hoë druk verdra nie - dit sou hom so duiselig mak dat hy nie kon lewe nie! Daarom besit die kameelperd bykomende strukture wat ander diere nie het nie. Daar bestaan 'n verbinding tussen die slagaar wat die brein van bloed voorsien en die slagaar na die nekwerwels. Hierdie verbinding tap van die bloed af voordat dit by die brein 
kom. Verder verdeel die slagaar wat die brein voorsien in 'n groot aantal takkies om 'n sponsagtige struktuur te vorm net voordat dit by die brein kom, die rete mirabile. Die wande van die aartjies in die rete mirabile is elasties en absorbeer en stabaliseer die druk van die bloed wat daardeur vloei tot so 'n mate dat die bloed wat by die brein kom, onder alle omstandighede 'n egalige lae druk het. So kan die brein altyd fisiologies normaal funksioneer.

Hier het ons dus die lang nek, die spesiale klepstelsel in die are en die ander faktore verantwoordelik vir die hoë bloeddruk sowel as die strukture wat sorg vir die verlaging en gelykmaking van die druk van die bloed wat die brein voorsien. Die dier kan nie leef nie as selfs net een van hierdie strukture of meganismes sou ontbreek.

Sou dit wees dat die strukture of meganismes op 'n lukraak, ongerigte manier deur genetiese foute op dieselfde tydstip in dieselfde diersoort ontstaan het? Geen redelike wetenskaplike kan dit glo nie. Dit maak inteendeel in alle opsigte sin dat die kameelperd na sy eie aard volledig geskape is om in die hoë boomtoppe te wei.

Die natuurwetenskaplike wat daagliks die wonderlike verskynsels in die natuur vir homself moet oordink, uitpluis en verwerk, kan nie anders nie as om tot die gevolgtrekking te kom dat dit alles die werk is van die almagtige, transendente God. Die natuurwetenskaplike wat sy Bybel lees word genoop om saam met Paulus te bely „o Diepte van die rykdom en wysheid en kennis van God!”. Daar is dus volkome verenigbaarheid tussen die Bybel en die wetenskap.

Die gelowige wetenskaplike bestudeer die verskynsels in die natuur soos hy hulle huidig met al die gesofistikeerde tegnieke kan waarneem en probeer dan vanuit die bekende die onbekende verskynsels en ontdekkings van die verlede sover moontlik verklaar. $\mathrm{Hy}$ besef egter ook deeglik dat daar nog vele verborgenhede is wat God nie aan die mens geopenbaar het nie. Is dit nie 'n meer rasionele benadering tot die wetenskap as dié van die evolusionis nie?

Gelewer 19 Oktober 1981 voor G.T.V. Pretoria 